\title{
Hegemonic practices of online local fashion brands in the information society era during the Covid-19 pandemic
}

\section{Praktik hegemoni merek fashion lokal online di era masyarakat informasi selama pandemi Covid-19}

\author{
Wifkil Mu’tamiroh ${ }^{\bowtie}$, Bagong Suyanto \\ Department of Sociology, Faculty of Social and Political Sciences, Universitas Airlangga \\ Surabaya, 60286, East Java Province, Indonesia \\ E-mail of corresponding author: wifki194@gmail.com
}

\begin{abstract}
The Covid-19 pandemic has had an impact on people around the world, including in Indonesia, particularly regarding the social and economic aspects of life, including the online economic agents. This study looks at and analyzes the hegemonic practices carried out by online economic agents in relation to the consumer so then they can survive and benefit during the Covid-19 pandemic. The theory used is hegemony according to Antonio Gramsci. This study used a qualitative research design. The research subjects were the owners of online local fashion brands that have developed in East Java. The primary data was collected from interviews and secondary data is from books and journal articles. The results of this study show that the local brands had a good level of performance during the Covid-19 pandemic, as seen from the observations conducted on Instagram. Hegemonic practices by online economic agents consist of three methods. First, there is using the social media platform Instagram. Second, there is always being productive. Third, there is collaborating with social media influencers (endorsement). The hegemonic practices happened by the social media so that it can influence people to follow their Instagram accounts and buy the products offered.
\end{abstract}

Keywords: Covid-19 pandemic; local brands; hegemony practices

\section{Abstrak}

Pandemi Covid-19 telah berdampak pada masyarakat di seluruh dunia, termasuk di Indonesia, khususnya menyangkut aspek kehidupan sosial dan ekonomi, termasuk para pelaku ekonomi online. Kajian ini melihat dan menganalisis praktik hegemoni yang dilakukan oleh pelaku ekonomi online terkait dengan konsumen agar dapat bertahan dan mendapatkan keuntungan selama pandemi Covid-19. Teori yang digunakan adalah hegemoni menurut Antonio Gramsci. Penelitian ini menggunakan desain penelitian kualitatif. Subjek penelitian adalah pemilik merek fashion lokal online yang berkembang di Jawa Timur. Data primer diperoleh dari wawancara dan data sekunder dari buku dan artikel jurnal. Hasil penelitian ini menunjukkan bahwa merek lokal memiliki kinerja yang baik selama pandemi Covid-19 terlihat dari pengamatan yang dilakukan di Instagram. Praktik hegemoni oleh pelaku ekonomi online terdiri dari tiga metode. Pertama, ada yang menggunakan platform media sosial Instagram. Kedua, selalu produktif. Ketiga, berkolaborasi dengan influencer media sosial (endorsement). Praktik hegemoni yang terjadi di media sosial tersebut dapat mempengaruhi masyarakat untuk mengikuti akun Instagram dan membeli produk yang ditawarkan.

Kata Kunci: pandemi Covid-19; local brand; praktik hegemoni

\section{Introduction}

The Covid-19 pandemic has struck almost all parts of the world. Data from 30 December 2019 to 31 January 2021 shows that there have been 103,135,007 positive cases of Covid-19 globally so far (World Health Organization 2021). Meanwhile in Indonesia, based on the data reported by the Task Force for the Acceleration of Covid-19 Handling from the beginning of March 2020 to the end of January 2021, there have been 1,078,314 positive cases, of which 873,221 people were declared cured and 29,998 people died (Satuan Tugas Penanganan Covid-19 2021). The epidemic undoubtedly has had a tremendous impact on people's lives. The impact of this pandemic has been experienced by the community in all aspects of life, including their social lives and the economy (Berawi 2020). When observed from the perspective of economic life in Indonesia, several impacts have been felt, including increased layoffs and dismissals for workers by more than 1.5 million, a decline of 45.3 for the Purchasing Managers Index (PMI) Manufacturing Indonesia in March 2020, a decline in imports by 3.7\% year-to-date (ytd) in the first quarter of 2020 and an increase in inflation/prices in general. This has been continuous up to $2.96 \%$ year-on-year in March 2020 (Hanoatubun 2020; Yamali \& Putri 2020). Socially, the Covid-19 outbreak has also affected the level of poverty (Suryahadi et al. 2020).

The current conditions have definitely affected socio-economic mobility in Indonesia. A study conducted by Prawoto et al. (2020) revealed the relationship between the Covid-19 pandemic and the socioeconomic mobility of people in Indonesia with two possibilities as the respective outcomes, which are positive and negative respectively. The negative relationship occurs in the tourism, shopping, and 
pharmaceutical, gardening, transportation, and office sectors, while the positive relationship occurs in the residential sector. This means that the higher the level of distribution, the higher the number of people living at home (Prawoto et al. 2020).

Apart from the impacts occurring in the community, there is an interesting phenomenon where some groups of people can survive and even benefits from the Covid-19 pandemic. These groups of people are online economic agents. This can be seen in the data on people's consumption behavior during the pandemic. Based on the data from the Director of Analytic Data Advertising (ADA) Indonesia, two new behaviors have occurred in society during the pandemic, namely adaptive shoppers and workingfrom-home professionals (Amalia 2020). The results of the ADA analysis of Indonesia showed that the visits to shopping centers (malls) have also declined. The average decline in visits to several shopping centers was by more than $50 \%$ compared to the beginning of 2020 . These changes can be seen through the use of shopping and productivity applications throughout March 2020. The ADA data showed that these two types of applications are widely used by the public, particularly among the middle and upper classes. Regarding the adaptive shoppers, since social distancing was implemented, the use of shopping applications has increased by up to $300 \%$ (Lubis 2020).

Changes in the consumption behavior in the community during the pandemic have not only occurred in Indonesia. Several studies have showed that these changes have also occurred in several other countries. A study entitled 'Online Consumption during the Covid-19 Crisis: Evidence from Japan' showed that the Covid-19 pandemic outbreak has caused changes in the consumption patterns within the community. This was shown by an increase in the consumption of goods and services online through e-commerce (Watanabe \& Omori 2020). The development of e-commerce has also happened in Bangladesh. A study by Neger and Udin (2020) explained that during the Covid-19 pandemic, the amount of online shopping performed by the community has increased. The factors influencing people when shopping online during the pandemic include the products, time-saving (efficiency), payment, and the administrative, and psychological factors. These factors were found to have a strong and positive relationship with the online shopping behavior of the community during the Covid-19 pandemic in Bangladesh (Neger \& Uddin 2020). This phenomena is a great opportunity for people involved in the economic field, particularly those who can take advantage of developments in technology and information (internet) (Donthu \& Gustafsson 2020). This is because changes in the consumption behavior of the community during the Covid-19 pandemic cannot be separated from the use of the internet (Sheth 2020). The development of technology and information has led to various innovations as in the economic field, various media outlets have been provided so then the public (economic agents) can benefit from them (Cartwright et al. 2021; Olanrewaju et al. 2020). One example of an economic innovation that can be seen during the Covid-19 epidemic is the use of more digital technology where the business models conducted by the Indonesian people often include the utilization of social media in order to market their products to the public (consumers) (Mahriani 2020).

In this era of an information society, there are groups of people who can make good use of internet media in the economic field. This community group involves the owner of online local brands. Local brands have popped up ranging from food products (culinary) to fashion. Data from a survey by the Creative Economy Agency showed that the fashion sector is one of the leading sectors because of its role in the growth of the creative economy (BEKRAF 2020) Along with technological developments, people are finding it easier, especially the millennial generation, to find out information about fashion (Mackey et al. 2017). Currently, fashion is essential. The development of fashion in the current era can be seen from the many local brands that have emerged in the community. Various types of fashion choices are also offered to the public including t-shirts, shirts, shoes, jackets, skirts, pants, hijabs, hats, and other accessories.

Indonesian local brands currently provide products that are not only affordable but have excellent quality. The existence of these local brands has become trendsetting in terms of presenting the fashionable styles to society with a flair for uniqueness. Several of the previous studies have explained the changes in people's consumption behavior, fashion developments and the presence of local brands during the pandemic, but none have explained in more detail the process of the brand owners maintaining their business venture. The focus in this study is on the hegemonic practices of the local fashion brand owners that have developed in several regions of East Java. The local brands that have developed in several regions of East Java include Giyomi (Surabaya), Rokgaliya (Malang), Uniche Gallery (Surabaya), Kelana Scarf (Pandaan), Kimka Hijab (Sidoarjo) and Prior.id (Sidoarjo). Some of the local brands have had a good existence during the Covid-19 pandemic so far as can be seen by the activities performed on social media or on the shopping platforms used. Based on the activities carried out by the owners of the online local fashion brands on social media, it can be seen that the interactions are outstanding. This raises the enthusiasm of the consumers for the products offered. 
This research uses hegemony theory as the focus of the analysis. Hegemony is explained by Gramsci as the process of domination by the dominant class in relation to the lower class. Meanwhile, the lower class is also active when it comes to supporting the ideas of the dominant class. However, the control is performed not through the use of violence but through forms of consent from the controlled society (Strinati 2010). Gramsci's concept of hegemony cannot be separated from Marxist thoughts because hegemony is a theory that was born from the thoughts of the Marxists in Russia when they faced the Russian monarchy. Therefore, almost all debates related to hegemony emerge from the flow of Marxism thought (Boothman 2008). However, the concept of hegemony is currently positioned to be more neutral in terms of how it views the various forms of power relations regarding their political, literary, economic, social, and cultural aspects (Hutagalung 2004). Based on the explanation of the background above, this article discusses how economic groups (online local fashion brand owners) can survive and even make a good profit during the Covid-19 pandemic by looking at the performance and hegemonic practices carried out.

\section{Research Methods}

Research into the hegemonic practices of "online local fashion brands" in the information society era during the Covid-19 pandemic was conducted to analyze how the online economic agents (local brands) have maintained their business during the pandemic. The results of this study are expected to provide an overview to the public about how to work in the economic sector, particularly in the era of the digital economy. This study used a qualitative research design to obtain more detailed data related to the phenomenon being studied. This study was conducted with a focus on online brand owners in the fashion sector in several regions in East Java. East Java was chosen as the research location because it has potential as can be seen from the existence of several brands originating from the East Java region on Instagram.

The first data collection technique used was secondary data collection about the development of local Indonesian brands available from the Creative Economy Agency (BEKRAF). In addition, other supporting data was also obtained from books and journal articles. Second, the primary data was collected by conducting in-depth interviews with the local brand owners in order to obtain more detailed information regarding the focus of the discussion. This included looking into the way they carry out the strategies required to maintain their business during the Covid-19 pandemic and the ways they influence (hegemony) the community so then they remain interested in the products offered. The determination of the informants was adjusted according to the predetermined criteria in accordance with the phenomenon being studied. First, the local brands had to have more than 100,000 followers on Instagram. Second, the local brands had to be located or developing in the East Java region. Third, the local brands had to be seen to be active on Instagram during the Covid-19 pandemic.

According to the three predetermined criteria, six informants were found who were successfully interviewed. The informants determined included the brand owners Giyomi (Surabaya), Uniche Gallery (Surabaya), Rokgaliya (Malang), Kelana Scarf (Pandaan), Kimka Hijab (Sidorajo) and Prior. id (Sidoarjo). In addition to the six subject informants, interviews were also conducted with six nonsubject informants. The criteria for the non-subject informants was people who followed and had bought products from the selected local brands. Interviews with the non-subject informants were conducted to provide additional information regarding the local brands. In addition to conducting interviews, primary data was obtained by making observations on the social media platform Instagram in order to determine the performance and activities of the local brands that had become the research subject during the Covid-19 pandemic. After obtaining the primary and secondary data, data processing was carried out. Data processing was conducted qualitatively by classifying and categorizing the data based on several themes according to the focus of the research (Suyanto \& Sutinah 2007).

First, there was the writing of the interview transcripts, categorizing the data according to the material studied, and then interpreting the data using the chosen theory, namely Antonio Gramsci's hegemony theory. The interpretation of the discussion also discussed the findings and results of the previous studies to complement the data obtained. Based on the data processing carried out, it was concluded how the online economic agents (local brands) in the fashion sector are able to survive during the Covid-19 pandemic, as well as what hegemonic practices have been practiced so then they can make people continue to choose products from the subject informants in this study. The discussion presented in this article is the final result of the data processing which will be presented in a simplified way to facilitate the readers' understanding. 


\section{Results and Discussion}

\section{The information society era}

The $21^{\text {st }}$ century can be said to be the information society era. An information society is a society with the opportunity to access information rapidly and precisely, or a society that is identical to the use of technology. It has the primary mission of creating a society that is aware of the importance of information, science, and technology, in addition to the creation of an integrated, coordinated, and documented information service. The dissemination of information to the wider community is done so rapidly, accurately, and in a manner that is useful (Laxman 2007). An information society is characterized by information behavior, which is the overall behavior of the society that is directly associated with information sources and channels.

An information society has the following characteristics: (1) the information sources can be reached by all levels of society, (2) there is public awareness of the importance of information in various life activities, (3) the community has open views and perspectives on utilizing technology and information efficiently, (4) library institutions, documentation, and information are developed equally, (5) the human, information, and physical resources that utilize science and technology are getting more advanced and (6) the information is well managed, presented timely and packaged in technology that can be developed as a commodity with economic value (Sutarno 2006). At present, it is obvious that all people feel that there has been a rapid development of technology and information. The successful development of the information society can be realized if all components are established simultaneously and concurrently. In Gulbe's (2020) study, the general objectives of community development are to develop an economy based on knowledge and innovation while providing sustainable economic and social benefits from a single digital market based on the internet (Gulbe 2015).

To achieve these objectives, certain steps must be taken including opening up access to the content, making online and cross-border transactions directly, building digital trust, strengthening the single market for telecommunications services, increasing interoperability through coordination, trust, and security, ensuring universal broadband coverage with increasing speeds, an open and neutral Internet, improving digital literacy, skills and inclusion, providing sustainable health care and ICT-based support for a dignified and independent life (Gulbe 2015). The development of technology and information in Indonesia has started to be felt. It has had a profound impact on all aspects of life in the community, particularly regarding the social and economic aspects. Regarding the current phenomenon, information is a highly calculated economic raw material (Bethune et al. 2019; Clemons et al. 2017). Currently, there are various kinds of features available on social media that can help economic agents to promote their products, for example, such as on Facebook and Instagram, as well as various shopping platforms such as Tokopedia, Lazada and Shopee.

\section{Performance of local fashion brands during the pandemic}

In Indonesia, the development of fashion can be said to be quite rapid as can be seen by the emergence of several local brands. All brands compete to display the quality and characteristics of their products. The presence of various online shopping platforms and social media also plays an active role in encouraging the local brands to keep growing and to be recognized by the public. The price offered is relatively affordable when compared to well-known international brands, although they are of high quality. Therefore, it is not surprising that people switch to buying products from the local brands. East Java has good potential in terms of production. This has been proven by the local fashion brands that are either located or established in several cities in East Java. The local fashion brands include Giyomi (Surabaya), Rokgaliya (Malang), Uniche Gallery (Surabaya), Kelana Scarf (Pandaan), Kimka Hijab (Sidoarjo), and Prior.id (Sidoarjo). In the ongoing Covid-19 pandemic situation, it is a challenge for local brand owners to maintain the business or commerce. They must be able to innovate to maintain their existence. Various strategies have been performed by the brand owners of Giyomi, Rokgaliya, Uniche Gallery, Kelana Scarf, Kimka Hijab, and Prior.id so then their business can survive and continue to grow.

Giyomi is a clothing brand from Surabaya City. Giyomi's characteristics are timeless, minimalist, and with a simple design. The performance of this local brand is quite good as can be seen from the activities seen on Instagram. First, Giyomi updates its story feature every day with photos and videos. The photos and videos also vary. They are not only products from the catalogs but also specially made to greet their consumers/followers. It can be said that Giyomi exists because, during the pandemic, it has continued to produce new products and has even collaborated with Indonesian celebrities. Besides, in order to captivate the hearts of the public who are following Giyomi's brand account, the brand holds a giveaway once a week. 
Rokgaliya is a brand that developed in Malang city. This brand has the distinctive feature of specifically manufacturing skirts. In the ongoing pandemic situation, Rokgaliya also seems to continue to exist as can be seen from its activity on Instagram. Rokgaliya uploads a story to its Instagram account every day. The content uploaded is relatively diverse, ranging from catalog photos to videos describing the products to be sold. Rokgaliya also occasionally holds an event to get it closer to the community, particularly its followers/consumers. The event is a search for a model called the "face of Rokgaliya." This selection is expected to bring the consumers closer, particularly during the pandemic.

Uniche Gallery is a brand focused on shoes and sandals from Surabaya. Based on the owner of the Uniche Gallery's revelation, during the pandemic, the brand felt confused because it often participated in bazaar events held in several cities before the pandemic, besides focusing on the online business world. The situation forced all of the brand's activities to be done online. To maintain its business endeavors, Uniche Gallery is always thinking of creative ideas so then the brand remains visible to the public. The brand actively creates content on Instagram in the form of stories and feeds. It is not uncommon for the owner of Uniche Gallery to ask questions of the consumers/followers about the shoe or sandal model that they want. In this way, Uniche Gallery hopes that the consumers/followers will feel involved when they are making new products to sell.

Kelana Scarf is a clothing brand located in Pandaan. Besides focusing on the online business world, Kelana Scarf also has an offline store. The offline store opened earlier this year to support the pioneering business. However, during the pandemic, online sales have been more effective as many people are afraid to leave their homes. The performance of Kelana Scarf has remained active during the pandemic. Based on the statement by the brand owner, the number of orders has been getting higher. The activities performed involve actively creating content on Instagram. It also collaborates with influencers such as celebgrams (an Instagram celebrity). This method is considered to be a more effective method than traditional advertising.

Kimka Hijab is a clothing brand located in Sidoarjo city. Typical products from Kimka Hijab are clothes in cute styles for women, particularly the millennial generation. Kimka Hijab's brand performance is also relatively good as seen from the content posts on its Instagram, on which it always updates every day. According to a statement of the owner of the Kimka Hijab, the brand has managed to obtain more orders from its followers than before the pandemic. The brand's strategies during this pandemic involve always improving their product quality and bringing in several new models. Kimka Hijab is also more dynamic in terms of providing information about the brand to the public while continuing to actively perform on its Instagram.

Prior.id is a brand originating from Sidoarjo city. The products of this brand are women's bags. This local brand has also been seen to be active on Instagram during the Covid-19 pandemic. In accordance with the statement of the brand owner, Prior.id has experienced a quantity increase in turnover during the pandemic. However, this has been accompanied by a great effort from the brand. The brand owner of Prior.id stated that they have made an extra effort to survive during the pandemic. For example, the information and promotions on the products were provided by the brand owners using the Instagram ads feature before the pandemic. During the pandemic, the brand owner has combined two methods by continuing to use Instagram ads and collaborating with celebgrams (Instagram celebrities) to promote their products. Furthermore, similar to the five previous brands, Prior.id also actively creates content on Instagram in the form of stories and feed posts.

The description of each brand above shows that the creativity and innovation that has been performed has led to quite good results. The creativity and innovation that are performed cannot be separated from the facilities due to the advancements made in technology and information. The local brand owners have found that the existence of social media, especially Instagram, is very helpful when marketing products to the public (Manitoba Analytics 2020). Given that in this era the majority of people use gadgets to access information, especially during the pandemic, the community use gadgets a lot because they are spending more time at home. Based on the results of a previous study, $37 \%$ of its respondents stated that since social distancing was enforced, they had downloaded one or more e-commerce applications. They claimed to spend their time on social media (Dahiya et al. 2020).

This kind of situation certainly has implications regarding the changes in people's shopping patterns. People are more often at home to perform their transactions. By using gadgets, the consumers will have access to wider preferences regarding their shopping destinations. They will be more likely to find out about a product and be able to compare the price offered by various sellers (Fatoni et al. 2020). 


\section{Hegemonic practices of local fashion brands during the pandemic}

The various available facilities are evidence of the rapid development of technology and information. This can definitely be used by online economic agents, as has been done by the brand owners of Giyomi (Surabaya), Uniche Gallery (Surabaya), Rokgaliya (Malang), Kelana Scarf (Pandaan), Kimka Hijab (Sidoarjo), and Prior.id. (Sidoarjo). The brand owners compete to provide information to the public about the existence of their products. In the previous sub-chapter, the results of the observations on Instagram have highlighted the performance of the local brands during the Covid-19 pandemic. From this explanation, it can be seen how the brand owners show the public that their brands remain active and productive. One of the aspects that has been engaged by the local brand owners indirectly is the process of providing information to the public in the hope that the people will trust the products offered. Borrowing a concept from Antonio Gramsci, some of the activities performed by the brand owners are known as hegemony. Hegemony means that the local brand owners try to provide various information in particular ways about their products to the public. Therefore, people are unconsciously interested in what the local brand has displayed. Based on the interview data and observations, the hegemonic practices performed by the six brand owners who became the subject informants during the Covid-19 pandemic will be explained in the following paragraphs.

\section{The use of Instagram to build interactions}

The brand owners pay attention to public trust. During the pandemic, the brand owners of Giyomi (Surabaya), Uniche Gallery (Surabaya), Rokgaliya (Malang), Kelana Scarf (Pandaan), Kimka Hijab (Sidoarjo), and Prior.id (Sidoarjo) have had intense interactions with the community and their followers on Instagram. The brand owners have utilized the features provided by Instagram by updating the "story" feature every day. The content displayed also involves different forms of creativity. The Giyomi brand from Surabaya always displays photos and videos with interesting concepts. The model and shooting location are fairly well displayed. Uniche Gallery, a brand from the same city, actively greets its followers a little differently. The content uploaded is commonly from a live photoshoot, for example, displaying the ready stock items in the store.

Besides engaging in online sales, Uniche Gallery also has a shop. Therefore, they often brand their offline stores in their uplouds. Rokgaliya, similar to the previous local brands, always builds its interactions by updating its stories like the others. This is done by posting about the products to be released. Rokgaliya also often holds live Instagram sessions to directly review the products that are to be sold. It can respond to any questions from its followers directly. Recently, Rokgaliya also held an event named the "face of Rokgaliya", with the hope of getting closer to its followers. Furthermore, the local brand Kimka Hijab from Sidoarjo also builds good interactions on Instagram. The owner of Kimka Hijab is directly involved in greeting its followers, posting all content and monitoring the responses and questions from its followers. This is done to strengthen the relationship with the brand's followers.

The next local brand is Kelana Scarf, which is also actively creating content on Instagram every day. One of the innovations of this brand is opening an offline store this year that can also be seen in every post on its Instagram account. Finally, the local brand Prior.id, a local bag brand from Sidorajo, is also actively updating its content on Instagram. Slightly different from the other brands, the owner of this brand is actively involved in catalog shooting. The model for each photo catalog is Prior.id's owner in most posts. During the Covid-19 pandemic, it was recognized by the brand's owner that it needed hard work to keep it going. Although the turnover has increased, the effort on the marketing side has also been added, one of which is by optimizing the use of features on InstagramThe local brand's content on Instagram during the pandemic has not only been limited to product information. Some have actively carried out giveaways. Instagram is also used as a means of interaction when creating further products. It is not uncommon for each brand to share questions related to the content in the story feature regarding people's tastes regarding the latest fashion trends. As is well known, there is a poll feature on Instagram. This is a feature that is well utilized by the brand owners when building interactions. The owner of Prior. id brand stated the following: "Asking what's trending, for example Korean dramas or what can I do as content, because content is not just about selling, so I try to interact with my followers" (informant LG).

Following the effort that has been put in by the brand owners, it can be seen that there is a hegemonic process involved. This is where the community is served daily with product reviews, provided with the latest fashion through the designing of each superior product by the local brands, and where they are involved in the process of making the next collection. In this way, the Giyomi, Uniche Gallery, Rokgaliya, Kelana Scarf, Kimka Hijab, and Prior.id brands can influence and gain the public's trust. Even during the pandemic, buyer loyalty is still very good. 
Table 1.

Performance of the brand and its hegemonic practices

\begin{tabular}{|c|c|c|c|}
\hline Brand & Location & $\begin{array}{l}\text { Performance } \\
\text { during the } \\
\text { Covid-19 } \\
\text { pandemic }\end{array}$ & Hegemonic practices \\
\hline Kimka Hijab & Sidoarjo & Active & $\begin{array}{l}\text { 1. Utilizing Instagram to increase interaction with } \\
\text { followers by directly handling Kimka Hijab's In- } \\
\text { stagram account } \\
\text { 2. Updating the story feature on Instagram every } \\
\text { day } \\
\text { 3. Focusing on producing clothes that have be- } \\
\text { come Kimka Hijab's signature and increasing } \\
\text { the number of bestselling clothing productions } \\
\text { 4. Using celebrity services to introduce Kimka Hi- } \\
\text { jab's products }\end{array}$ \\
\hline Kelana Scarf & Pandaan & Active & $\begin{array}{l}\text { 1. Utilizing Instagram to increase its interactions } \\
\text { with its followers by updating the story feature } \\
\text { on Instagram every day } \\
\text { 2. Producing more diverse clothing than before } \\
\text { the pandemic } \\
\text { 3. Using celebrity services to introduce their prod- } \\
\text { ucts } \\
\text { 4. Opening an offline store to support their sales }\end{array}$ \\
\hline Prior.id & Sidoarjo & Active & $\begin{array}{l}\text { 1. Utilizing Instagram to increase its interaction } \\
\text { with its followers by handling the Prior.id's In- } \\
\text { stagram account directly and even becoming a } \\
\text { catalog model for the products } \\
\text { 2. Using the Instagram Ads feature to promote a } \\
\text { product } \\
\text { 3. Using celebrity services to introduce its prod- } \\
\text { ucts } \\
\text { 4. Holding a giveaway once a month }\end{array}$ \\
\hline Giyomi & Surabaya & Active & $\begin{array}{l}\text { 1. Utilizing Instagram to increase the interactions } \\
\text { with its followers using the story feature } \\
\text { 2. Using the poll feature on Instagram to increase } \\
\text { its engagement with its followers } \\
\text { 3. Bringing out fresh products, such as pajamas } \\
\text { 4. Collaborating with artists to create new prod- } \\
\text { ucts } \\
\text { 5. Using celebrity services to introduce its prod- } \\
\text { ucts } \\
\text { 6. Holding a giveaway once a month }\end{array}$ \\
\hline Rokgaliya & Malang & Active & $\begin{array}{l}\text { 1. Utilizing Instagram to increase its interactions } \\
\text { with its followers using the story feature } \\
\text { 2. Using the live Instagram feature to review prod- } \\
\text { ucts and greet its followers directly } \\
\text { 3. Holding the new face of Rokgaliya event } \\
\text { 4. Producing collections continuously } \\
\text { 5. Making innovations by producing comfortable } \\
\text { sportswear for women } \\
\text { 6. Using celebrity services to introduce products }\end{array}$ \\
\hline $\begin{array}{l}\text { Uniche } \\
\text { Gallery }\end{array}$ & Surabaya & Active & $\begin{array}{l}\text { 1. Utilizing Instagram to increase its interaction } \\
\text { with its followers using the story feature } \\
\text { 2. Using the poll feature to find out what followers } \\
\text { regarding new products } \\
\text { 3. Holding giveaways and discounts once a month }\end{array}$ \\
\hline
\end{tabular}




\section{Productive in terms of production}

Besides actively building its interactions through Instagram, the brand owners are always productive in terms of creating new models of its clothing, bags, shoes, and sandals according to the flagship products of each brand. It can be seen through the six brands' posts on Instagram that they are always updating with new products. It is recognized by the brand owners that it is done so then people have many shopping choices. The owner of the Kelana Scarf brand stated:

"Not thousands of pieces, if before the pandemic it was at least one hundred, it doesn't seem that much different, does that mean per product? The production per product is not much different, only if the products during this pandemic are more varied, so if the total is more so" (informant MT)

As stated by the owner of the Kelana Scarf brand, the total sales per item were reduced during the pandemic. However, if the total sales per item are summed up, it is the same as the amount of production before the pandemic. This is because the models produced during the pandemic are increasingly diverse. Likewise, the Prior.id and Uniche Gallery brands are actively seeking information about the current models and those that are currently a hit in society, particularly among the millennial generations and students. This information makes it easier to create products. The owner of the Uniche Gallery brand stated that before engaging in production, they upload photos first to see what their followers' responses are. Furthermore, the Prior.id owner also stated:

"Sometimes I share with my employees, they are still young, one is still in college, the other has
just graduated from college. So why am I looking for college kids? Because I'm still young and my
target is kids their age, so sometimes I share with them. What do young people like?" (informant
LG).

Unlike the three previous brands, the Kimka Hijab brand focuses on its best-selling products. During the pandemic, it has produced clothes that are always sought after by its followers. The owner of the Kimka Hijab Brand stated:

"No, in fact, there has never been a discount since the pandemic, so the most innovations such as new products (increasing the number) run out, it also increases the interaction with the followers. What's more, communication is the most important thing. So yes, how do these followers feel that they are accepted like that, so they stay and are very loyal to our products" (informant KK).

Based on the statement by the Kimka Hijab brand owner, the production of new models will definitely be carried out, but the process is quite long. Therefore, during the pandemic, Kimka Hijab is focused on producing clothing models that have become its signature, particularly the best-selling products. According to the owner, raising the name of Kimka Hijab is more essential at this time. Kimka is trying to continue to introduce its products through the media and increase the amount of clothing production that is always targeted at the public so as not to disappoint. Furthermore, the Rokgaliya and Giyomi brands can be said to be bigger than the previous four brands. During the pandemic, Giyomi has been actively releasing new products. Based on the statement by the owner of the Giyomi Brand, during the pandemic period, people must always be productive so then they keep following Giyomi's development. The brand does not want people to think that it is out of production or no longer trendy. One of the innovations during the pandemic made by Giyomi was making home clothes such as a set of pajamas designed with the latest models in mind, considering that many activities are now being engaged in at home during the pandemic. The owner of the Giyomi brand stated:

"From the brand side, we must continue to exist because customers, in any condition, have to maintain their trust, the point is that a brand or a business organization must remain active in creating content, productive in making products, maybe one of them is that we must prioritize cash flow, and home clothes are one of the innovations" (informant YD).

Similar to Giyomi, Rokgaliya is also actively producing during the pandemic. It seems that this brand releases flagship products regularly. This certainly makes the public enthusiastic. Rokgaliya also has engaged in innovations during the pandemic, including releasing new products for its range of modern sportswear. Sports is a new behavior engaged in by the community during the pandemic. Rokgaliya had the idea to produce sportswear for women. It offers comfortable sportswear for women without losing its characteristic, which is the basic skirt design. The owner of the Rokgaliya brand stated:

\footnotetext{
"Yes, it's affected, it's just that thank God we still have sales, just that, yesterday we got input from our marketing consultants, we collaborated with marketing consultants, the term we think more deeply about this corona condition. Finally, we think hard about how we can make products that can be in demand during this corona condition. Yesterday we had time to sell masks too. So the point is
} 
that every day you have to think more deeply, yesterday I made pajamas and thank God, we made pajamas in the first place in this corona, it can help sales and even become a big sale, for homey sets. The point is, we just set the strategy for the product. Yes, product innovation during this pandemic, yesterday made a skirt for updates, we made a skirt that can be used for sports because there are many people who exercise in pandemic conditions" (informant IG).

Therefore, it can be concluded that the six local brands have never stopped thinking about production ideas during the pandemic. Each local brand owner is trying to be productive. Accordingly, it can show its existence to the public by doing so. In this case, the visible hegemonic process is by serving the public with new or fresh products every day. An attractive product makes people interested in buying it. It was observed by the researchers that when Giyomi, Uniche Gallery, Rokgaliya, Kelana Scarf, Kimka Hijab, and Prior.id released a product or offered up an open order, usually by uploading stories, the community showed its enthusiasm.

\section{Collaborating with influencers (endorsement)}

Over the years, advertising is not the only way to promote products. With the development of information media, a new designation or profession has been established, which is that of the social media influencer. An influencer on social media can be defined as someone who is actively using their social media accounts who has a large number of followers. Social media influencers are third parties who provide product information to the public through social media. Furthermore, it is proven that product recommendations from social media influencers can affect consumer opinion (Hermanda et al. 2019). Examples of current social media influencers are celebgrams (Instagram), Youtubers (YouTube), Bloggers (Blog), and so on. The services provided by the influencers are also used by the six local brands in this study, particularly celebrities. Influencers (celebrities) have an influence over the followers on their accounts based on the content uploaded and what is written on their Instagram (Anjani \& Irwansyah 2020). This is recognized by the six brand owners in this study. According to the owner of the Kelana Scarf Brand, a celebgram 's endorsement is currently the most effective way to get a product seen compared to advertising. Although the price is more expensive, the benefits are also larger. The same thing was stated by the brand owners of Kimka Hijab, Prior.id, Uniche Gallery, Giyomi and Rokgaliya, in that celebgrams can help to introduce the products of each brand to the public. During the pandemic, the brand owners also remain active by endorsing the celebrities. This can be observed on the Instagram of each local brand and in the posts by the celebgrams who introduce their products.

Even during the pandemic, the Giyomi brand collaborated with Indonesian celebrities. Giyomi released a product with Cut Syifa. It attracted the attention and enthusiasm of the public, particularly Giyomi's loyal followers. This can be seen by the uploaded story on Giyomi's Instagram account. As the product was released, it was quickly hunted down by their followers. During the pandemic, Prior.id has also combined two ways of promoting. The catalog photo modelling was usually performed by the owner, and now the brand is also using an endorsement model to maximize the marketing process. Based on the above phenomenon, it can be concluded that the hegemonic process occurs when the local brand owners use the services of Instagram influencers (celebgram). The posts uploaded by the celebrities increase their followers' interest in following the accounts of each brand, and some may even be interested in buying. This happens because the influencers already have the trust of the public, considering that the major criteria for the effectiveness of the activities taken by digital influencers are trust as an authority, the credibility of the message communicated, and the relationship between the message and a particular person (Wielki 2020). Therefore, through the endorsement method performed by the brand owners of Giyomi, Uniche Gallery, Rokgaliya, Kelana Scarf, Kimka Hijab, and Prior.id, the process of hegemony in the community occurs effectively when selling or introducing products to the public. Several methods have been used by the local brand owners to maintain their performance during the pandemic. The six local brand owners have implemented different strategies in order to remain active and productive (Table 1). This was done in order to get the attention of the public (consumers) during the pandemic because during the pandemic, people spend more time at home.

\section{Conclusion}

During the Covid-19 pandemic, people's shopping behavior has experienced a shift from offline to online shopping. This is evident from the results of the Analytic Data Advertising survey that showed a decrease in the number of community visits to shopping malls. This means that online economic agents, especially local brands, play an active role during the pandemic. Based the presentation of the results of this study, it can be concluded that local brands that play an active role include Giyomi, Uniche Gallery, Rokgaliya, Kelana Scarf, Kimka Hijab and Prior.id. These six brands have used several methods to maintain their existence during the pandemic. In the information society era today, almost all people cannot be separated from the use of technology to find information such as information about 
the development of the fashion world. This can be seen from the performance of the six brands where the local brand owners utilized social media, particularly Instagram. Their performance can be observed from the posts uploaded on Instagram every day. Updates are made in the form of product introductions to the public. This is carried out by the owners of the local online fashion brand to build their interactions with the community. Therefore, the brand owners can show that their brands are still there and that they are more productive during the Covid-19 pandemic. Besides introducing products, the brands actively greet the public when giving updates on Instagram stories by sharing opinion polls. This is done in the hope that they can become closer to their followers. It can be said that these six brands have performed well during the pandemic.

One method that has been done by the owners of these local brands as analyzed using the Antonio Gramsci concept is hegemony. Hegemony is defined as the process of influencing the community without using violence, indicating that the community agrees with what the local brand owners do. There were three kinds of hegemony practices performed by the six local brands. The first was using Instagram to build interactions with the community. Each brand utilized several features on Instagram to build its interactions, including stories, feed posts, live sessions, and the Instagram Ads features. Regarding the features provided by Instagram, the local brands in this study have used them to share photos and videos related to the products to be sold. The photos and videos that are provided every day are packaged attractively so then people are interested in buying them. These features are also used to explain the details and advantages related to the product that is to be released. Second, the brands are always productive which shows good performance during the pandemic. The local brand owners are always active and productive. It can be seen that the hegemonic practices carried out by each local brand include always displaying or offering contemporary products. Two brands have even innovated to make clothing according to the current conditions, where many people are at home and doing new activities, such as sports. Therefore, the innovation carried out is to issue home clothes (pajamas) and sportswear. With the release of new products done continuously, people are unconsciously attracted to the products that are sold by the brand owners. Third, the brands collaborate with social media influencers (endorsement). Celebgrams can be said to be highly influential regarding the sales of the six local brands. All of the local brand owners admitted that they always use a celebgrams's endorsement. The practice of hegemony begins when the celebgrams post photos or videos on their Instagram accounts. The information shared by the celebgrams increases the public interest in buying, at least enough for them to follow the Instagram account of each brand. Therefore, it can be concluded that maintaining the performance of the local brands of the subjects of this study cannot be separated from the hegemonic practices involved. The hegemonic practices in the information society era are associated with the development of technology. Local brands can develop and survive during the Covid-19 pandemic with the help of social media. By using social media, they can easily influence people to follow their Instagram accounts and buy the products offered.

\section{References}

Amalia HA (2020) Social distancing munculkan dua perilaku baru. [Accessed 17 June 2020]. https:// investor.id/lifestyle/social-distancing-munculkan-dua-perilaku-baru.

Anjani S \& Irwansyah (2020) Peranan influencer dalam mengkomunikasikan pesan di media sosial Instagram (the role of social media influencers in communicating messages using Instagram). Polyglot: Jurnal Ilmiah 16 (2):203-229.

BEKRAF (2020) Laporan Kinerja Badan Ekonomi Kreatif 2019. Jakarta: Badan Ekonomi Kreatif Indonesia.

Berawi MA (2020) Empowering healthcare, economic, and social resilience during global pandemic Covid-19. International Journal of Technology 11 (3): 436-39.

Bethune Z, Bruno S \& Nicholas T (2019) An Information-based theory of financial intermediation, 19-12. [Accessed 6 December 2020]. https://ssrn.com/abstract=3473118.

Boothman D (2008) The sources for Gramsci's concept of hegemony. Rethinking Marxism 20:201-15. doi:10.1080/08935690801916942.

Cartwright S, Davies I \& Archer-Brown C (2021) Managing relationships on social media in businessto-business organisations. Journal of Business Research 125 (March 2020):120-34. doi: 10.1016/j. jbusres.2020.11.028.

Clemons EK, Dewan RM, Kauffman RJ \& Weber TA (2017) Understanding the information-based transformation of strategy and society. Journal of Management Information Systems 34 (2):42556.

Dahiya K \& Potia A (2020) Optimistic digital generous: Covid-19's impact on Indonesian consumer sentiment. The Jakarta Post. [Accessed 7 December 2020]. https://www.thejakartapost.com/ academia/2020/04/19/optimistic-digital-generous-covid-19s-impact-on-indonesian-consumersentiment.html. 
Donthu N \& Anders G (2020) Effects of Covid-19 on business and research. Journal of Business Research 117:284-89. doi:10.1016/j.jbusres.2020.06.008.

Fatoni, Nur S, Susilawati C, Yulianti L \& Iskandar (2020) Dampak Covid-19 terhadap perilaku konsumen dalam penggunaan e-wallet di Indonesia. Thesis, UIN Sunan Gunung Djati, Bandung.

Gulbe M (2015) Quantitative characteristics of information society and ICT industry in Latvia. Procedia Economics and Finance 26 (15):682-87. doi:10.1016/s2212-5671(15)00810-2.

Hanoatubun S (2020) Dampak Covid-19 terhadap prekonomian Indonesia. Journal of Education, Psycology, and Counseling 2 (1):146-53.

Hermanda A, Sumarwan U \& Tinaprillia N (2019) The effect of social media influencer on brand image, self-concept, and purchase intention. Journal of Consumer Sciences 4 (2):76-89.

Hutagalung D (2004) Hegemoni, kekuasan dan ideologi. Jurnal Pemikiran Sosial, Politik dan Hak Asasi Manusia 12:1-17.

Laxman PP (2007) Perpustakaan Digital: Perspektif Perpustakaan Perguruan Tinggi Indonesia. Jakarta: Sagung Seto.

Lubis MSW (2020) Begini perubahan perilaku konsumen gara-gara corona. [Accessed 17 June 2020]. https://ekonomi.bisnis.com/read/20200414/12/1227101/begini-perubahan-perilaku-konsumengara-gara-corona.

Mackey A, Wakkary R, Wensveen S \& Tomico O (2017) Can I wear this? Blending clothing and digital expression by wearing dynamic fabric. International Journal of Design 11 (3):51-65.

Mahriani E (2020) Model bisnis di tengah pandemi Covid-19. Jurnal Hadratul Madaniyah 7 (1):9-14. doi: $10.33084 / \mathrm{jhm} . v 7 \mathrm{i} 1.1596$.

Manitoba Analytics (2020) Impact of advertising on consumer behaviour. [Accessed 15 November 2020].https://www.gov.mb.ca/agriculture/markets-and-statistics/economic-analysis/pubs/impactof-covid-on-consumer-behaviour.pdf.

Neger M \& Udin B (2020) Factors affecting consumers' internet shopping behavior during the COVID-19 pandemic: Evidence from Bangladesh. Chinese Business Review 19 (3):91-104.

Olanrewaju AST, Mohammad AH, Naomi W \& Paul M (2020) Social media and entrepreneurship research: A literature review. International Journal of Information Management 50:90-110.

Prawoto N, Eko PP \& Abitassha A (2020) The impacts of Covid-19 pandemic on socio-economic mobility in Indonesia. International Journal of Economics and Business Administration 8 (3):5771.

Satuan Tugas Penanganan COVID-19 (2021) Peta sebaran Covid-19. [Accessed 31 January 2021]. https://covid19.go.id/peta-sebaran-covid19.

Sheth J (2020) Impact of Covid-19 on consumer behavior: Will the old habits return or die? Journal of Business Research 117:280-283.

Strinati D (2010) Popular Culture Pengantar Menuju Teori Budaya Populer. Jogjakarta: Ar-Ruzz Media.

Suryahadi A, Ridho A \& Daniel S (2020) Estimating the impact of Covid-19 on poverty in Indonesia. Bulletin of Indonesian Economic Studies. doi: 10.1080/00074918.2020.1779390.

Sutarno NS (2006) Perpustakaan dan Masyarakat. Jakarta: Sagung Seto.

Suyanto B \& Sutinah (2007) Metode Penelitian Sosial Berbagai Alternatif Pendekatan. Jakarta: Prenadamedia Group.

Watanabe T \& Yuki O (2020) Central bank communication design working paper series online consumption during the COVID - 19 crisis: Evidence from Japan. JSPS Grant-in-Aid for Scientific Research (S) 023(023):39.

Wielki J (2020) Analysis of the role of digital influencers and their impact on the functioning of the contemporary on-line promotional system and its sustainable development. Sustainability (Switzerland) 12 (17):1-20.

World Health Organization (2021) WHO coronavirus disease (COVID-19) dashboard. [Accessed 31 January 2021]. https://www.who.int/health-topics/coronavirus.

Yamali FR \& Ririn NP (2020) Dampak pandemi Covid-19 terhadap ekonomi Indonesia. Ekonomis: Journal of Economics and Business 4 (2):384-388. 